\title{
How Computerization changes the UK Labour Market: The Facts viewed from a new perspective
}

Citation for published version (APA):

Borghans, L., \& ter Weel, B. J. (2000). How Computerization changes the UK Labour Market: The Facts viewed from a new perspective. Researchcentrum voor Onderwijs en Arbeidsmarkt, Faculteit der Economische Wetenschappen. ROA Working Papers No. 7E https://doi.org/10.26481/umarow.200007E

Document status and date:

Published: 01/01/2000

DOI:

10.26481/umarow.200007E

Document Version:

Publisher's PDF, also known as Version of record

\section{Please check the document version of this publication:}

- A submitted manuscript is the version of the article upon submission and before peer-review. There can be important differences between the submitted version and the official published version of record.

People interested in the research are advised to contact the author for the final version of the publication, or visit the DOI to the publisher's website.

- The final author version and the galley proof are versions of the publication after peer review.

- The final published version features the final layout of the paper including the volume, issue and page numbers.

Link to publication

\footnotetext{
General rights rights.

- You may freely distribute the URL identifying the publication in the public portal. please follow below link for the End User Agreement:

www.umlib.nl/taverne-license

Take down policy

If you believe that this document breaches copyright please contact us at:

repository@maastrichtuniversity.nl

providing details and we will investigate your claim.
}

Copyright and moral rights for the publications made accessible in the public portal are retained by the authors and/or other copyright owners and it is a condition of accessing publications that users recognise and abide by the legal requirements associated with these

- Users may download and print one copy of any publication from the public portal for the purpose of private study or research.

- You may not further distribute the material or use it for any profit-making activity or commercial gain

If the publication is distributed under the terms of Article $25 \mathrm{fa}$ of the Dutch Copyright Act, indicated by the "Taverne" license above, 


\title{
How Computerization changes the UK Labour Market: The Facts viewed from a new Perspective
}

\author{
ROA-W-2000/7E \\ Lex Borghans and Bas ter Weel ${ }^{*}$
}

* Lex Borghans: Research Centre for Education and the Labour Market (ROA), Maastricht University. Bas ter Weel: Maastricht Economic Research institute on Innovation and Technology (MERIT), Maastricht University. We would like to thank Harrie Borghans, Andries de Grip and Hugo Hollanders for their commentary on an earlier version.

Research Centre for Education and the Labour Market

Faculty of Economics and Business Administration Maastricht University

Maastricht, November 2000 
The paper benefited from discussions with Jim Allen, Josh Angrist, Eli Berman, Harrie Borghans, Andries de Grip, Hans Heijke, Hugo Hollanders, Francis Kramarz, Alan Krueger, Victor Lavy, Jasper van Loo, Steve Pischke, Judith Semeijn, Luc Soete and Oxana Tchervonnaya. Seminar participants at the Dutch Central Bank, Maastricht University and the Dutch Ministry of Social Affairs are also gratefully acknowledged for their comments and suggestions. We would like to thank Francis Green for providing us with the data from the Skills Survey of the Employed British Workforce we use in this paper. Finally, we thank Nic van Hal for his excellent research assistance and Alan Felstead for his help with analysing the data. 


\section{Contents}

Page

Abstract

1 Introduction 1

2 Findings 6

3 The impact of ICT on the workplace 16

3.1 Who uses ICT? 17

$\begin{array}{ll}3.2 \text { Productivity, demand and wages } & 19\end{array}$

$\begin{array}{ll}\text { 3.3 Which skills are important? } & 20\end{array}$

3.4 Required educational level 20

3.5 Is work getting more complex or more standardized? 21

4 Conclusions and policy implications 22

5 References 24

$\begin{array}{ll}\text { Appendix } & 29\end{array}$ 



\begin{abstract}
The digitisation of the world as a result of the introduction of computers, chips, and ICT, has undoubtedly been the most important technological development of the past few decades. The fact that more and more workers use computers has led to the conclusion that computer skills are becoming a key to social success. The aim of this paper is to contribute to the discussion of the effects of computerization on work. Our main conclusions are that the fear of a digital split in society appears unjustified. Although computers initially find their way primarily to the higher educated, practically all workers eventually end up working with computers. Absence of computer skills probably plays no role during this process of computerization. This does not mean, however, that there is no need for policies to optimise the economic potential of computers and ICT in general. Firstly, a properly developed infrastructure may be of importance for a rapid diffusion of the possibilities offered by ICT. This applies not only to the physical networks, but also to the availability of software and information. In addition, it may be expected that the educational requirements for workers will increase across the board and there will be changes in the knowledge and skills that people need to have. These are not primarily computer skills, but concern a much wider shift in the importance of various skills. Adjusting adequately to these changes requires reliable data. What is being measured and how the measurements are taken, will need to change considerably.
\end{abstract}

Keywords: Wage Differentials by Skill; Computer Use and Skill JEL Classification: J30; J31 


\section{Introduction}

New machines are often regarded as a threat. Although there is generally great appreciation for the cleverness of inventors who create the first automobile, radio or chess-playing computer, and many people want to see such marvels with their own eyes, inventions of this kind often inspire fear of the changes that the introduction of new techniques and technology may bring about. Naturally, this fear is partly justified. Charlie Chaplin's Modern Times (1936) shows a victim of the assembly line, who ends up in a psychiatric institution and is happier there than on the assembly line. Then there is the coachman, who was so adept at handling his horses, but whose skills were no longer relevant after the arrival of the motorcar, just like the perfection of chess computers will put the performance of professional chess players in a different perspective. The fear for loss of jobs has therefore often been a source of protest against the introduction of new technology. When, many years later, everyone has become used to the new technology and society has adapted to the possibilities it offers, people often laugh when they look back at the fear they had of the new and the unknown. Remarkably, the implications of the new technique or technology proved much greater than they initially suspected, creating a great deal of new employment.

The digitisation of the world as a result of the introduction of computers, chips, and modern information and communication technology (ICT), has undoubtedly been the most important technological development of the past few decades. At the time of the introduction of the computer during the sixties and the emergence of automation in the seventies, the widespread use of PCs, the emergence of the Internet in the eighties and nineties, and the current innovations in the field of (mobile) telecommunication, there has been fear that people would lose their jobs or that sections of the population would miss the boat, creating a (digital) division of society.

Initially, the computer was primarily regarded as a device that took over work and carried it out more efficiently. The first computer-controlled robots welded, sprayed, and built cars that had previously been assembled by human beings; computers took over administrative tasks from bookkeepers; and in the process industry, computers independently took decisions on the progress of the production process on the basis of measuring data from the plant. The idea arose that computers would take over more and more work from human beings. In the future, even translators would probably be replaced by the translation computer. Many economists, but even more so the general population, were therefore afraid that computers and ICT would take over much of the work presently done by human beings, and that large sections of the population would lose their jobs. ${ }^{1}$

As it is easier to automate simple work, the lower educated would be the ones to suffer most from the rise of the computer. Spenner (1985) suggested that the demand for labour would increasingly show a U-shaped cycle. On the one hand, much of the high-skilled labour would

1. See e.g. Soete $(1987)$ and Freeman and Soete $(1994,1997)$ for an overview of this line of thought. 
hardly be affected by computerization; the advent of the computer even demands more highskilled experts who develop computers, operate them and write programs, while on the other hand, the work of the lower skilled B if they retained any work at all B would become simpler. They would only need to press the button to switch the machine on and watch whether everything worked properly. The craftsmanship or professional skills in the centre of the spectrum would disappear. Figures 1 and 2 show that in the early days of the computer revolution, this $U$-shape in fact seemed to emerge.

Figure 1

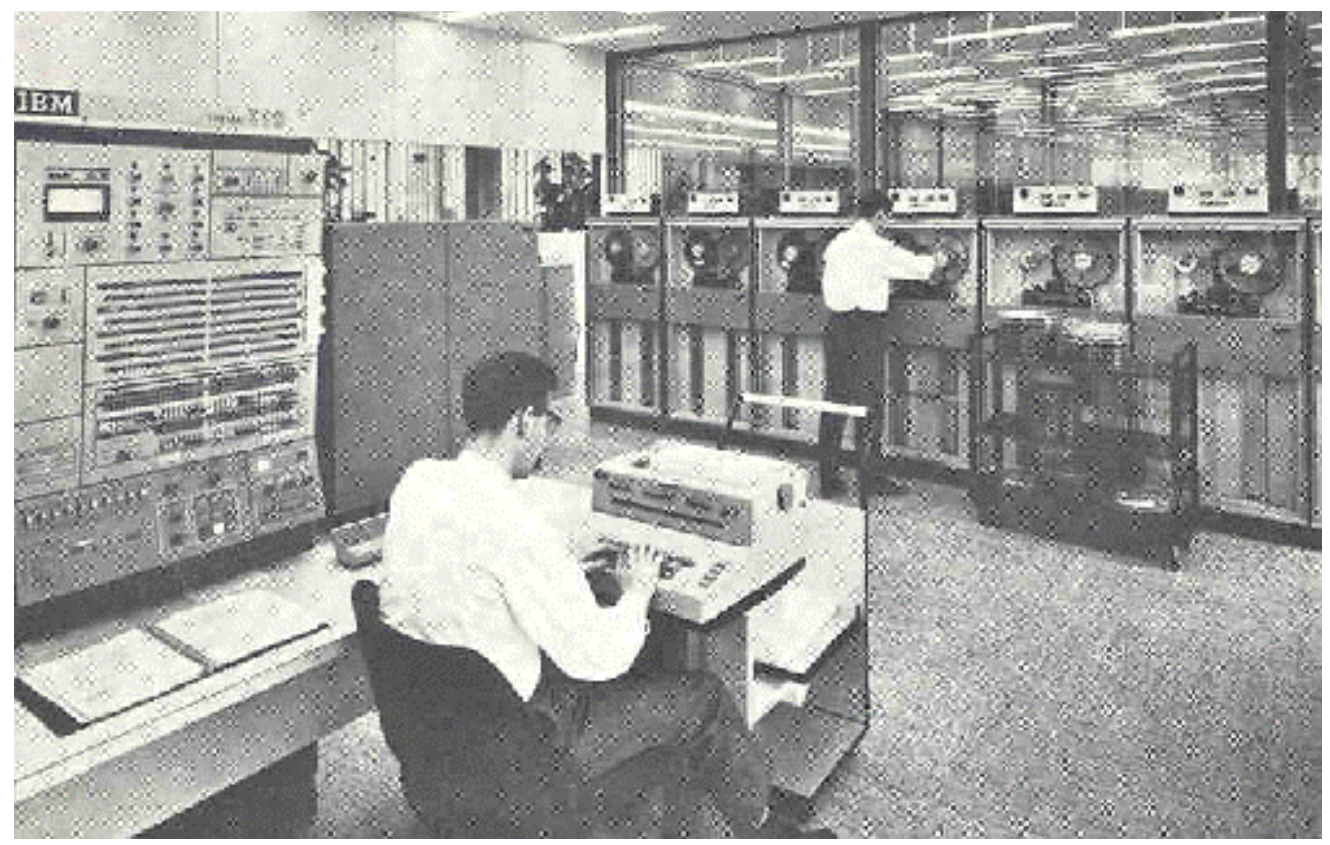

Computer operators operating an IBM System 360, Model 50. It is evident that operating a computer during the sixties required a high level of computer skills.

Source: Lohberg and Lutz (1968)

For many people, the dramatic increase of unemployment in Europe since the end of the seventies seemed to confirm the idea that automation would cause the loss of many jobs. This fear of loss of employment as a result of the advent of the computer has determined employment policies for a long time. The analysis of unemployment in the European White book on growth, competitiveness and employment from 1994 still referred to technological unemployment. The defeatist scenario of mass technological unemployment, however, never became reality. As the OECD (1994) stated: "History does not support the case for technological unemployment." There are two reasons for this.

Firstly, the computer has not only taken over work that was already done previously, but this new technology in all its manifestations, has also offered a tremendous variety of possibilities for new products, new methods and enormous savings on the costs of certain production processes. The new opportunities have created many new jobs, which require not only higher educated workers. 


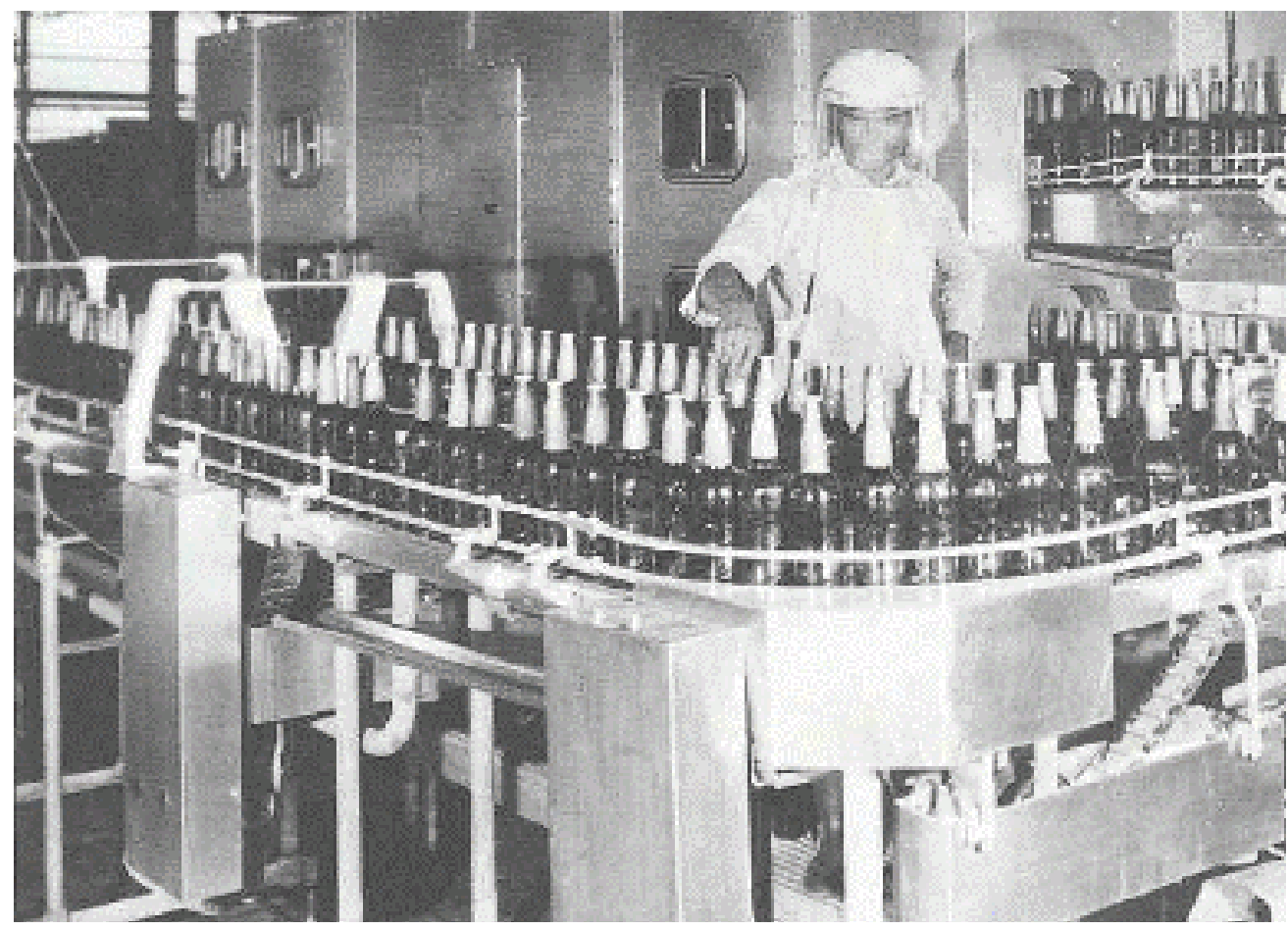

A man monitoring the production process. Occasionally, he will interfere in the process.

Source: Reader (1980)

Examples of new products include a range of electronic devices, such as watches, computer games, but also mobile phones, which have not only generated jobs in development, but also in manufacture and sales. Call centres and help-desks are primary examples of new activities, which have only become possible because of computer technology and have created many jobs, particularly for workers at the intermediate level. As software that has been developed is relatively easy to adapt to new applications, the production costs of many devices have dropped considerably. Whereas a television set with pre-set buttons used to require a separate, expensive, and vulnerable electronic circuit for each button, the adaptation of a TV set from 12 to 100 pre-set stations is now only a marginal change in a parameter of the software concerned.

The second reason why the doom scenario of mass unemployment never materialized, is that it has become clear that the computer is not replacing workers, but that workers have increasingly started to work with computers. Technology is adapting to the user, instead of the work and the organisation adapting to the technology, as was often assumed. The new technology is then usually regarded as an external entity, which is ultimately beyond control and to which man should adapt. By not staying abreast of modern technology, the international competitiveness of the country or the company could be endangered, triggering a sequence of negative effects. That the computer has obtained a completely different role is clearly illustrated by the term personal computer, because the PC eminently symbolizes the 
symbiosis between man and machine. While there were hardly any computers on the desks at the beginning of the eighties, the PC has by now become indispensable, not only at work but increasingly also at home. ${ }^{2}$

As a result of this rapid increase of PC usage, the fear that computers will take over our work has made way for the fear that people will not be able to work with computers. The fact that more and more workers use computers and that computers are increasingly used for private purposes too, in particular via the Internet, and thus will become more important, has led to the conclusion that computer skills are becoming a key to social success. Terms such as 'ICT illiterates' refer to the danger of society soon facing the fact that only part of the population knows how to operate a computer. ${ }^{3}$ Again, there is fear of a split in society. To ensure that everyone learns to use computers, major investments are made in computers in schools, all pupils get their own email addresses and there are plans to introduce tax benefits for the purchase of PC equipment. These measures should minimise the number of people who miss the boat. ${ }^{4}$

Although the views on the influence of computers on employment have changed dramatically, the diagnosis remains that in particular the higher educated will benefit from this new technology, while the lower educated run the risk of not being able to keep abreast of these developments. Since David Ricardo's work in the nineteenth century, much has been written on this relationship between technological development and employment

2. The PC has also made its way into education. In 1999, the number of pupils per PC was 18.0 in the United Kingdom. In the United States the number of pupils per PC was much lower: 8.0. In Canada, the ratio is 9.8, in Finland 15.1, in France 25.1, in Italy 92.6, in Japan 36.1, in the Netherlands 21.8, in New Zealand 18.4 and in Norway 15.4 pupils per computer (see Anderson and Ronnkvist (1999)).

3. The Anglo-Saxon polarization of rich and poor would create a kind of 'haves' and 'have-nots' as a result of the progress of technology: a society of individuals who are well adept at ICT and all matters related, and who make a good living, against a group of ICT illiterates, who are poor and unable to find jobs with reasonable wages, and hence remain unemployed.

4. The Secretary of State for Education and Employment David Blunkett argued in a speech on the $3^{\text {rd }}$ of November 1999 the following: "We are working to ensure that the ICT age does not bring about a wider gap between the haves and the have nots." The Second Report of the National Skills Task Force (1999, p. 66) puts its fear for a digital divide as follows: "Overcoming 'technophobia' is only the foundation in strengthening adult competence in the use of IT. Targets should be set for adult participation in IT opportunities that have sufficient scope and rigour to ensure real proficiency in the basic use of information and communication technology, including key software applications such as word processing, to meet national standards." Finally, the Department for Education and Employment (1999, p. 165) has initiated "£418 million for additional, innovative capital projects form the first round of the Capital Modernisation Fund. A further $£ 50$ million was announced for ES modernisation." Furthermore, "capital investment in schools will ensure that standards are raised by improving the condition of school buildings and with the provision of up-to-date ICT to suit the curriculum of the $21^{\text {st }}$ century. Investment of $£ 5.9$ billion is being made in school buildings and £270 million on the National Grid for Learning (over the three years 1999-00 to 2001-02)." (p. 16). 
(Ricardo (1821)). The key question is always whether these technological developments decrease the demand for - in particular - the lower educated. In modern jargon, this is the debate on 'skill-biased technical change'. There seems to be growing consensus among economists concerning the fact that technological changes during the past sixty years have not merely increased productivity and hence decreased labour, but that there is in fact a growing demand for higher educated workers. ${ }^{5}$ Griliches (1969) and Acemoglu (1998) observed that high-skilled labour is complementary to capital, while low-skilled labour and capital are substitutes of one another. The emergence of modern ICT has probably accelerated this upgrading of the demand for labour, in spite of the greater supply of highskilled workers since the sixties in most OECD countries.

There is, however, no consensus yet on the way in which computers and other new technologies are changing the labour market. The complementarity between high-skilled labour and capital that is found in many studies, is a purely statistical observation. When the amount of capital increases, the demand for higher educated workers will also increase. But little is known about how exactly this works. To be able to understand the effects of the emergence of ICT, it is important to gain more insight in the way in which this technology has changed work. In this paper, we will show that - just like the idea that computers took over the work of the lower skilled proved to be wrong - the view that only those who can work with computers can be successful on the labour market in the $21^{\text {st }}$ century, appears to be losing credibility. Although the complementarity between capital and high-skilled labour is not subject to discussion, adequate insight in the meaning of computers for work is of great importance not only for policies on education, training and employment, but also for technology policies and policies aimed at international competitiveness.

The aim of this paper is therefore to contribute to the discussion of the effects of ICT on work. In Section 2, we will first list the main findings concerning computers at the workplace. Section 3 discusses how these findings can be explained on the basis of an analysis of the interaction between man and machine, and its implications for the developments on the labour market. In Section 4, we explain the meaning of this analysis for policies.

The main conclusions are that the fear of a split in society appears unjustified. Although computers initially find their way primarily to the higher educated, practically all workers eventually end up working with computers. Absence of computer skills probably plays no role during this process of computerization. This does not mean, however, that there is no need for policies to optimise the economic potential of ICT. Firstly, a properly developed infrastructure may be of importance for a rapid diffusion of the possibilities offered by ICT. This applies not only to the physical networks, but also to the availability of software and information. In addition, it may be expected that the educational requirements for workers will increase across the board. There will certainly be changes in the knowledge and skills

5. See e.g. the studies by Katz and Murphy (1992), Goldin and Katz (1998), and Murphy and Welch (2000) for the United States and Machin and Van Reenen (1998) and Berman, Bound and Machin (1998) for several OECD countries. Berman and Machin (2000) analyse 'skill-biased technical change' in developing countries. 
that people need to have. These are not primarily computer skills, but concern a much wider shift in the importance of various skills in our society. Adjusting adequately to these changes, requires reliable data. What is being measured and how the measurements are taken, will need to change considerably. It is significant to observe that in most countries hardly any serious attempts have been made to map these labour market developments. In this paper, we will therefore illustrate the developments resulting from the introduction of computers using data for the United Kingdom. These data are drawn from the Skills Survey of the Employed British Workforce, which is a unique survey containing detailed information about the skills needed on the computerized labour market. ${ }^{6}$

\section{Findings}

In a pioneering article, Alan Krueger (1993) wonders how computers have changed the structure of wages. His article presents two important findings. Firstly, he shows that between 1984 and 1989 in the United States, computers were primarily used by the higher educated. The rapid diffusion of computers may have increased their use among the lower educated, but at any one time their rate of penetration is higher as the educational level increases. Without explicitly saying so, Krueger shows that the assumption that computerization simplifies or even replaces the work of the lower educated, is false. Rather, there seems to be direct co-operation between computers and the higher educated. For other countries and different periods, this relationship between educational level and computer usage is also found. ${ }^{7}$

Table 1 shows an overview of computer usage in 1992 and in 1997 in the United Kingdom for the six educational levels that are distinguished in this country. ${ }^{8}$ These figures also prove that the use of computers at the workplace is growing. Of all university educated workers, no less than 95.5 per cent used a computer in 1997. For graduates with a professional qualification, the percentage was 88.9. Among the higher educated, a saturation point is being reached, but the use of computers is still growing, regardless of the qualifications. The total growth of computer usage during the period 1992-1997 was no less than 47.2 per cent.

6. To promote the development of better measuring tools for skills, the Skills Measurement and Economic Analyses conference was held in Canterbury in March 2000. The main papers presented at this conference will be published in a special issue of Oxford Economic Papers (Borghans, Green and Mayhew (2001)).

7. For example, Groot and De Grip (1991) show that banks increased their required qualifications after the introduction of a computerized system. Autor, Levy and Murnane (2000b) show for another bank that not only the demand for certain skills increases but also that computerization led to the substitution of computers for some unskilled tasks. Autor, Katz and Krueger (1998) show that computers in the workplace lead to a demand shift in favour of college graduates relative to highschool graduates.

8. The appendix to this paper shows a short and descriptive overview of the Skills Survey of the Employed British Workforce. For an extensive review of the survey we refer the interested reader to Ashton, Davies, Felstead and Green (1999). 
The largest increase in computer usage was found among workers who have no qualification, while at the intermediate level (NVQ 2 and NVQ 3) the increase was also greater than at the top.

Table 1

Use of computers at work among workers in the United Kingdom in 1992 and 1997, per educational level

Educational level $\quad$ Computer usage 1992

$(\%)$
Computer usage 1997 Percentage of increase

(\%) 1992-1997

\begin{tabular}{llll}
\hline Degree & 66.9 & 95.5 & 42.8 \\
$\begin{array}{l}\text { Professional } \\
\text { qualification }\end{array}$ & 66.4 & 88.9 & 33.9 \\
NVQ 3 & & & \\
NVQ 2 & 50.8 & 75.1 & 47.8 \\
NVQ 1 & 47.1 & 71.6 & 52.0 \\
No qualification & 38.0 & 55.1 & 45.0 \\
Total working & 25.3 & 40.2 & 58.9 \\
population & 47.0 & 69.2 & 47.2 \\
\hline
\end{tabular}

Note: $\quad$ The percentages stated in columns 2 and 3 are percentages for the entire group reviewed in a row for 1992 and 1997

Source: Skills Survey of the Employed British Workforce

Krueger's second major finding was that there appears to be a strong relationship between wages and computer usage. As it is in particular the higher educated who appear to use computers, this seems an obvious relationship. Krueger shows, however, that even if we correct for educational level, occupation, and a number of other common explanations for wage level, computer users still earn considerably more. In Krueger's case, this computer wage premium is 15.0 per cent in 1984 and even rises to 17.6 per cent in 1989. Later work by Autor, Katz and Krueger (1998) shows that this computer wage premium goes up to 22.5 per cent in 1993. This analysis has meanwhile been carried out many times for different countries, different years and using different data sources. Each time, a considerable computer wage premium is found. $^{9}$

9. Studies for other countries include Miller and Mulvey (1997) for Australia; Reilly (1995) for Canada; Entorf and Kramarz (1997), and Entorf, Gollac and Kramarz (1999) for France; DiNardo and Pischke (1997), and Borghans and Ter Weel (2000b) for Germany; Oosterbeek (1997), and Borghans and Van Loo (1999) for the Netherlands; Machin (1996), Green (1999), Green, Felstead and Gallie (1999), and Haskel and Heden (1999) for the United Kingdom; and Berman, Bound and Griliches (1994), Levy and Murnane (1996), Doms, Dunne and Troske (1997), Autor, Katz and Krueger (1998), Bresnahan, Brynjolfsson and Hitt (1998), Dunne, Foster, Haltiwanger and Troske (2000), and Weinberg (2000) for the United States. Studies for more than one country include Caroli and Van Reenen (1998) for France and the United Kingdom; Card, Kramarz and Lemieux (1999) for Canada, France and the United States; and Berman, Bound and Machin (1998), Machin and Van Reenen (1998), and Desjonqueres, Machin and Van Reenen (1999) for a number of OECD countries. 
We also find a similar computer wage premium for the United Kingdom. Table 2 shows that this premium is 21.4 per cent in 1997. On the basis of the Skills Survey of the Employed British Workforce for the United Kingdom, a link can also be made with the degree of computer usage. The table shows that as the use of computers is more essential, the related computer wage premium increases.

Table 2

Computer wage premium in the United Kingdom in 1997, related to the importance of computer usage

Computer usage at work is

Computer wage premium (\%)

$\begin{array}{lc}\text { Essential } & 34.0 \\ \text { Very important } & 23.6 \\ \text { Fairly important } & 14.7 \\ \text { Not very important } & 12.2 \\ & \\ \text { Total wage premium } & 21.4\end{array}$

Note:We estimated the following equation: in $W_{i}=$ Xiâ + Ciá + å where in $W_{i}$ is the natural logarithm of estimated parameters, where (exp (á ) - 1) is the computer wage premium that is listed in the second column of the table. åis an error term with the usual assumptions. The equation was estimated using OLS

Source:

L. Borghans \& B. ter Weel (2000a, Table 2

On the basis of his findings, Krueger concludes that computer skills have come to play an essential role in the labour market. Computers appear not to have taken over the work of the lower skilled, but they demand skills that are present particularly among high-skilled workers. For this reason, computers are initially used largely by the higher educated and it even appears that (given the educational level) those who use computers earn considerably more than those who do not use a computer. Apparently computers skills are not distributed evenly among all. Hence, the scarcity of computer skills has raised the wages of those who possess computer skills. As the use of computers increased, employers have to employ more people who possess fewer computer skills. The premium for adequate computer skills has only increased as a result, according to the allocation argument of Krueger cum suis.

The idea that computers take over the work of the lower skilled workers has therefore given way to the idea that only the higher skilled can operate these computers. Caselli (1999, p. 78) states this as follows: "A technological revolution is the introduction of new types of machines. Machines of the new type are more productive than machines of the pre-existing types, but they can only be operated by workers who have developed a set of machinespecific skills. The acquisition of such skills is costly, and the labour force is of course heterogeneous in the cost of acquisition. The revolution is skill-biased if the new skills are more costly to acquire than the skills required to operate the old machine. On the other 
hand, the revolution is de-skilling if the new skills can be acquired at a lower cost than the skills associated with pre-existing technologies."

According to this type of analysis, a major part of the increase in wage differences can be attributed to the emergence of the computer. The solution therefore seems obvious. Education will have to focus on computer skills much more than it has done so far. This would meet the increasing demand from employers for individuals who have good computer skills and would prevent a greater wage inequality. This analysis clearly reflects the view on computers that also appears to be dominant among the population and in policies. Many people take the odd computer course to familiarize themselves with Windows, a word processor or the Internet, afraid to lose touch with it all. They often buy a computer, because this would enable their children to become familiar with the new technology. A number of policy measures also seem to be based on the assumption that all youngsters need to enter the labour market with sufficient computer skills, because otherwise there is the threat of an unbridgeable gap and hence a split in society. Recent research, however, has shown this view to be incorrect. From various perspectives, research results are found that do not fit in this framework. We will discuss seven pieces of the jigsaw, which contradict the idea that computer skills are very important.

\section{Largest premium for email and word processing}

If we take a close look at Krueger's results, it appears that the largest computer wage premium goes to computer tasks such as emailing and word processing. These are hardly the skills that are reserved for the higher educated. Surprisingly enough, tasks that are carried out by computer programmers and specialist staff, such as programming and software design, are awarded with lower computer wage premiums than simple tasks such as emailing.

Table 3

Computer wage premium in the United Kingdom in 1997, related to the level of sophistication of computer usage

$\begin{array}{lll}\text { Advanced: } & \begin{array}{l}\text { programming } \\ \text { analysing data and making }\end{array} & 47.1 \\ \text { Complex: } & 34.4 \\ \text { Moderigns } & 29.2 \\ \text { Simple: } & \begin{array}{l}\text { word processing, spreadsheets } \\ \text { or email }\end{array} & 12.2 \\ & \begin{array}{l}\text { straightforward, such as printing } \\ \text { a cash register receipt }\end{array} & \end{array}$
Note: We estimated the following equation: in $W_{i}=$ Xiâ + Ciá + å where in $W_{i}$ is the natural logarithm of the hourly wages of individual $i, X_{i}$ is a vector of the observed personal characteristics of individual $i$, such as educational level, age, working experience, et cetera. $C_{i}$ is a matrix for the different levels of sophistication of computer usage at work. â and á are estimated parameters, where (exp (á ) - 1) is the computer wage premium that is listed in the second column of the table. å is an error term with the usual assumptions. The equation was estimated using OLS

Source: L. Borghans \& B. ter Weel (2000a, Table 2) 
Table 3 presents the computer wage premium in the United Kingdom, broken down at four levels of sophistication of computer use. In this classification, an increasing level of sophistication does appear to lead to a higher premium, but it also appears that even the simplest computer tasks, such as printing a sales slip, provide a wage premium of no less than 12.2 per cent. It is difficult to understand that the skills to operate a modern cash register instead of an old one justify a more than 10 per cent higher wage. In addition, the computer wage premiums for a moderate use of computers are also very high. Moderate use concerns in particular word processing and the use of spreadsheets. From the point of view that the computer wage premium is a reflection of the value of the skill concerned, there appears to be something wrong with these wage premiums.

\section{Many low and intermediately skilled workers use computers}

Most computer usage concerns emailing and word processing. This is not exactly the type of specialist knowledge that would only be available among high-skilled workers. Many lowskilled and intermediately skilled workers use computers. Bresnahan (1999) and Handel (1999) show that it is therefore not likely that 'skill-biased technical change' is caused by the need for high-skilled workers to operate computers. In particular many secretaries and typists use PCs intensively. This does not seem to indicate that the use of new technology primarily requires sophisticated skills.

\section{Is it true that computer usage leads to higher wages?}

A number of researchers interpret Krueger's computer wage premium as an indicator for the fact that the introduction of computers at the workplace increases wages. The computer is regarded as a 'treatment'. An employee who gets a computer, sees his wages go up, while an identical employee from an imaginary control group who does not get such a computer will not get this wage rise. The reasoning is that computers increase productivity and that the employee will subsequently have this productivity increase reflected in his wages. If we assume that there is competition on the labour market, it is not clear, however, why individuals with similar capabilities would not be rewarded similarly. In other words, there is no reason for an employer to pass on the increased productivity to the employee.

It is therefore more likely to assume that in particular those who have good computer skills are selected for the jobs in which computers are introduced. If computer skills gain importance because of the emergence of ICT, it may be expected, however, that this select group can look forward to a more rapid wage increase than the group of employees who have lower levels of computer skills. Chennells and Van Reenen (1998) and Entorf, Gollac and Kramarz (1999) therefore studied a panel of employees who started to use computers during the research period. They found that employees who started to use computers during the period investigated did not receive significantly higher wages than the group who did not start to use computers. Entorf, Gollac and Kramarz concluded that employees with the largest - non-observable - computer talent are selected by the company to use computers. Haisken-DeNew and Schmidt (1999) found similar results for computer usage in a German 
panel. Bell (1996), on the other hand, did find a considerable wage increase for computer usage. His study, however, covered a much longer period than the aforementioned analyses. A study by Entorf and Kramarz (1997) shows that employees who use computers, annually experience a wage increase that is about one per cent greater. They interpret this as the market value of the computer experience that individuals have acquired. It is debatable, however, whether this interpretation is correct. After all, the findings could also indicate that it is not the computer usage of each individual worker, but the increased market value of the group as a whole influences wages.

Companies with a high level of computer usage also pay higher wages to employees who do not use computers

The idea that the computer wage premium should first and foremost be regarded as an appreciation of individual computer skills, implies that only those who actually use a computer will get higher wages. Studies by Doms, Dunne and Troske (1997) and Dunne, Foster, Haltiwanger and Troske (2000), however, show that the computer wage premium is not an individual, but a company-related effect. They found that companies that work with advanced technology, such as computers, pay their employees more. It is irrelevant whether an employee uses a computer or not, he will nevertheless receive a wage premium. Furthermore, it is remarkable that in particular managers who do not themselves use the most advanced technology, receive the highest wage premium.

\section{People who have computer skills, by no means always use computers}

If computer skills are becoming more and more important in the labour market and increasing use of computers has made these skills a scarce commodity, it can be expected that employers will try to ensure that anyone who has such skills does work in which these are important. DiNardo and Pischke (1996), however, show that in Germany it is by no means the case that all those who have computer skills, are working in jobs in which computers are used. On the other hand, quite a large number of people have jobs in which computers are used, even though they have no computer skills.

Table 4

Relationship between computer usage in 1992 and in 1997

No computer in 1997 (\%) Has a computer in 1997 (\%)

No computer in 1992

$27.2 \quad 25.7$

Has a computer in 1992

3.6

43.5

Note: The sum total of the percentages amounts to 100 per cent

Source: Skills Survey of the Employed British Workforce

Also, people who use computers at work frequently switch to jobs in which computers are not used. Table 4 shows that in the United Kingdom, about four per cent of all employees 
used a computer in 1992, but no longer did so in 1997. This means that, contrary to the strong trend of increasing computer usage, about one in every twelve employees stops using a computer.

\section{The use of pencils also yields a premium}

DiNardo and Pischke (1997) took a critical look at Krueger's results by investigating whether it was only computer usage that explained remarkable wage differences. They therefore looked at the use of other attributes, such as pencils, calculators, telephones, and the fact whether a person did his work standing up or sitting down, to see whether any of these aspects could explain the wage differences. Apart from the computer wage premium, they found a similarly large premium for the use of pencils. From these results, they conclude that Krueger's computer wage premium is probably not an adequate measure for the importance of computer skills.

\section{Rewards appear to be unrelated to computer skills}

The six types of research results discussed above all cast doubt on the question whether the computer wage premium should be interpreted as a reward for computer skills. The questions that they raise concerning the presumed importance of computer skills, however, are always based on indirect evidence. These research results show that there is a need for a measure for computer skills in order to be able to analyse the importance of computer skills for the labour market directly. This need is acknowledged in the British Skills Survey of the Employed British Workforce. The latter survey for the first time asked respondents specifically for the level of their computer skills. ${ }^{10}$ The measure for computer skills runs from very high to very low computer skills. The data are only available for individuals who actually use computers. Table 5 gives the wage premiums for each skill level. Apart from the group that has very low computer skills, everyone appears to receive approximately the same computer wage premium. A surprising result is the fact that individuals with average computer skills receive the highest computer wage premium. Although the results of the four highest categories are statistically indistinguishable, this result is highly remarkable. It seems

10. In a survey, it is easy to confuse computer skills, computer usage, and the question whether the respondent knows what a computer does. In the Skills Survey of the Employed British Workforce, therefore, great care was taken to develop a question on computer skills. We know three other studies that use a direct, but less adequate criterion for computer skills. The first is Hamilton (1997). The latter used computer variables from the High School and Beyond Survey from 1986, which imply whether an individual has ever used software or used a computer language for programming purposes. His findings were that individuals who responded positively to these questions received a computer wage premium of about eight per cent. The second study was carried out by Bell (1996). Bell's analysis shows that computer talents cannot explain the wage premium. The third study that investigated the effects of computer skills in a direct way, is DiNardo and Pischke (1996). They found a higher return for computer skills in Germany, but Borghans and Ter Weel (2000b) showed that this is the result of an incorrect econometric specification. After careful analysis, it appeared that also on the basis of this criterion, computer skills are unimportant. 
to indicate that computer skills are not very important for the wages received, as long as the employee has some skills. The question 'do we need computer skills to operate a computer?' therefore seems a legitimate one. Only the group of individuals with very low computer skills appears to receive a much lower wage premium of 8.5 per cent. The group that states that they are hardly able to work with a computer adequately, however, is very small. Apparently a complete absence of computer skills is still an impediment for employment. It is remarkable, though, that these individuals still earn considerably more than similar individuals who do not use computers at work.

Table 5

Computer wage premium for five levels of computer skills

Very high

High

Intermediate

Low

Very low
22.9

23.2

25.1

22.1

8.5

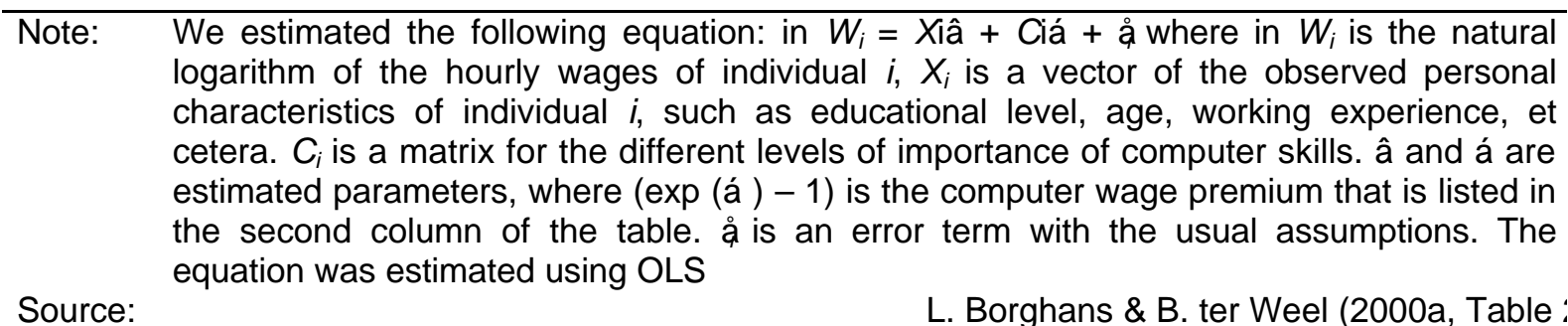

These seven pieces of the jigsaw puzzle that are difficult to fit in, have made a number of (labour market) economists doubt the validity of the idea that operating computers requires special and valuable skills. As an alternative explanation for the computer wage premium and the fact that in particular the higher educated use computers, they point at the possibility of so-called complementary skills (Levy and Murnane (1996)). Levy, Beamish, Murnane and Autor (1999) propose a framework in which skills are classified on the basis of what computers can do best and what human beings can do best. The idea is that a computer is in particular good at cold number crunching. To optimally use the possibilities offered by computers, the user must have skills that the computer does not possess. These complementary skills may vary from creativity in a designer, improvisation, analysis, and communicative skills in a manager, to the friendly voice of an employee in the call centre, or the helpfulness of a salesperson. So these may be both skills associated in particular with the higher educated, but also skills available in the intermediately and lower educated.

The higher wages received by workers who use computers, are then an expression of greater responsibility, adaptive capabilities, and development capacities. In other words, if we look at it from this point of view, there is no longer any 'skill-biased technical change' as a concept indicating a mere technical complementarity, in which the qualifications required for 
the use of new technology are, as it were, listed in a manual. From the perspective of complementarity, the computer facilitates the way in which human beings organise and communicate. From this point of view, 'soft skills' are increasingly important and 'skill-biased technical change' rather reflects an organisational development: the use of new technology does not so much require new technical skills, but also and in particular organisational capabilities, in which the new technological opportunities are utilised to take autonomous decisions and responsibilities. This would mean that the qualifications asked by employers are showing a gradual shift, which is consistent with the shift in Western economies from a fairly Taylorian way of organized industrial and service economy towards a knowledge economy. In this new economy, wider communicative, decisional and responsibility skills would rapidly gain importance besides specific technical skills (e.g. Murnane, Willett and Levy (1995) and Lindbeck and Snower (2000)).

Contrary to a computer, it is perfectly clear that the use of a mobile phone does not require special skills. On the basis of the idea of complementarity, the demand for skills is no longer directly linked with the technique, and hence it is no longer essential that shifts in the demand for higher educated workers is explained solely by the emergence of the computer. Recent technological breakthroughs in the field of communication technology (including the Internet and mobile telephony) have given a new impulse to the distribution and use of ICT in all sectors of the economy and have given rise to new forms of interaction and network utilisation of computers. As this technology becomes cheaper, this would cause the availability of highly qualified, but also and in particular flexible personnel that can translate and use this knowledge, to be essential within the contours of the organisation. Even more than in the case of computers, it can be expected that communicative skills will be the essential new training skills in information technology, which will be complementary to the use of ICT (e.g. Bresnahan (1999) and Bresnahan, Brynjolfsson and Hitt (1998)).

The research on the effects of the growing use of computers and ICT therefore concentrates increasingly on the question of which skills are complementary to the use of modern ICT. The search, however, is still in full flow and no hard findings are available yet. Table 6 shows which skills have the greatest value for those who use computers at a particular level of sophistication. This does not need to mean, however, that the value of these skills has also increased as a result of the introduction of the computer. For each level of computer usage (advanced, complex, moderate and simple), we looked at those skills from a group of 45 (besides computer skills) that yielded the highest wage premiums. ${ }^{11}$

It appears that computer skills are not important. For the advanced level of computer usage, the most important skills are thorough analysis of complex problems and finding the causes of problems and errors. That such skills are important when computers are used at an advanced level, is obvious. One of the main characteristics of a programmer is of course finding programming and other errors and setting up, analysing and building computer systems. The eventual entry in the computer and writing in programming languages appears

11. See the Appendix for an elaboration. 
to be of less importance. Working in a team and knowing how the organisation works are the most important skills of workers at a complex level of computer usage. Complex computer usage means that a worker uses the computer to analyse data and to create designs. This group includes people who work in the marketing departments of large companies, who develop strategies on the basis of sales figures. They may also be designers of advertising campaigns or billboards, who use complex drawing and graphics programs to create designs. If computers are only used moderately, thorough analysis of complex problems and creating speeches and presentations are the most important skills. The moderate level of computer usage means that the computer is used for word processing, working with simple spreadsheet programs such as Excel or Lotus, and reading and sending email. This is a varied group of individuals, ranging from managers to secretaries. This explains why both making thorough analyses of complex problems and creating speeches and presentations are important skills. Lastly, writing short documents and thorough analysis of complex problems are important when the computer is used for simple tasks.

Table 6

Two skills that have the greatest value for different levels of computer usage

Level of computer usage

\begin{tabular}{llll}
\hline Advanced & Complex & Moderate & Simple \\
\hline $\begin{array}{l}\text { Analysing complex } \\
\text { problems in depth }\end{array}$ & Joining in a team effort & $\begin{array}{l}\text { Analysing complex } \\
\text { problems in depth }\end{array}$ & $\begin{array}{l}\text { Writing short } \\
\text { documents with correct } \\
\text { grammar and spelling }\end{array}$ \\
$\begin{array}{l}\text { Working out the cause } \\
\text { of problems or faults }\end{array}$ & $\begin{array}{l}\text { Having knowledge or } \\
\text { understanding of how } \\
\text { the organisation works }\end{array}$ & $\begin{array}{l}\text { Making effective } \\
\text { speeches or } \\
\text { presentations }\end{array}$ & $\begin{array}{l}\text { Analysing complex } \\
\text { problems in depth }\end{array}$ \\
\hline
\end{tabular}

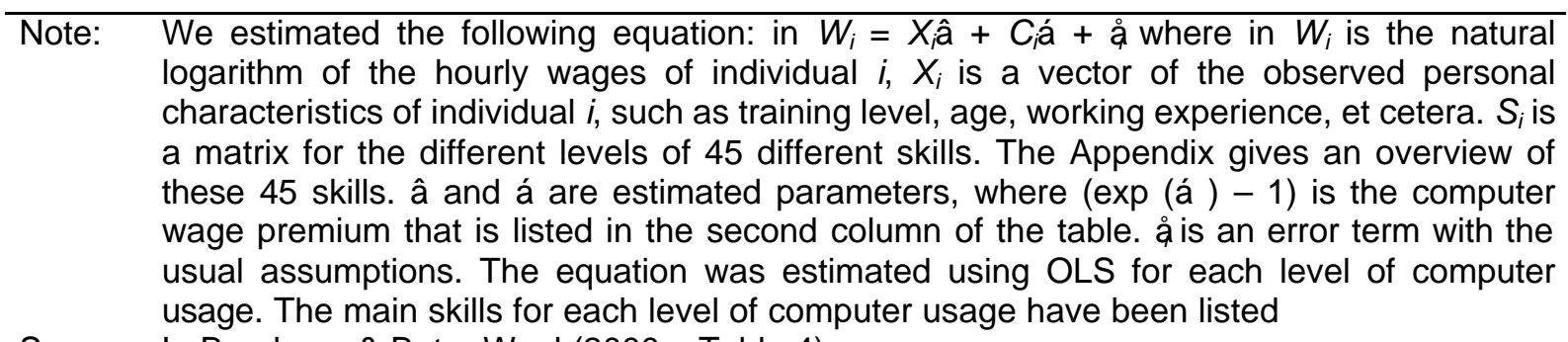
Source: L. Borghans \& B. ter Weel (2000a, Table 4)

It remains difficult, however, to explain all research results discussed in this section on the basis of the complementarity idea. If complementary skills are to explain Krueger's computer wage premium of about 20 per cent, one may wonder whether computer usage should not lead to higher wages, or whether individuals who do not use computers in a company with a high level of computer usage should also be rewarded for this, why people stop using computers, and how it is possible that pencils also yield a premium. The main problem for 
the moment is that research has been unable to clearly identify the complementary skills that are important enough to explain Krueger's very high computer wage premium.

To obtain a greater understanding of the importance of the introduction of computers for employment, and to gain more insight in the influence of computers on the knowledge and skills that are required for the labour market, we need to study in greater detail how computers are used and in what way the activities of workers and the organisation within the company adapt to this. Although little is known about this process, we will use the next section to throw some light on the possible meaning of computers for work, in order to place the empirical findings from the present section in a proper perspective. By factually analysing the implications of ICT for the work carried out by individuals, and by discussing the interaction between man and machine, we create a new framework within which most research findings can find a place.

\section{The impact of ICT on the workplace}

An essential characteristic of ICT is that this technology supports human beings in their activities. The equipment is somewhere near the individual's workplace. The PC with access to the Internet is on one's desktop, the mobile phone is in one's bag, and the computerized cash register is on the counter. On the one hand, ICT does not take over all work B as feared in Chaplin's Modern Times and during the sixties and seventies B rendering the worker superfluous. On the other hand, not all work is done using the new technology. Writing this paper, we spend a great deal of time with our PCs, but our co-operation with the computer remains limited. The computer registers which words we have already added to the report and helps us move paragraphs, correct the spelling, and print or email the text to each other or to others. A large part of the work B thinking about the message and the content of the paper B however, remains something that we do individually and that the computer cannot take over. It is therefore incorrect to assume that the computer takes over all work, reducing the tasks of human being to pushing the right buttons, inserting the correct disks, or possibly even soldering back a wire that has come undone, in order to ensure that the work is done properly by the computer, as shown in Figure 2.

To determine the influence of ICT on the way we work, it is useful to take a closer look. Borghans and Ter Weel (2000c) assume that before an employee receives certain ICT, he carries out two types of activities B Task 1 and Task 2 . It is interesting to analyse the consequences of the introduction of the computer in such a situation. Possibly, or even probably, these tasks are highly interrelated, but the only thing that is important is that, while ICT supports Task 1, it cannot support Task 2. Although the nature of and the required skills for the tasks may differ greatly, the interrelationship of the activities makes it impossible to separate the tasks into two different jobs, which would have enabled the appointment of two individuals, each of whom would be best qualified for one of the tasks.

In this simple framework, there are two key questions. The first question is of course, in which situations and when companies will decide to acquire ICT for a particular workplace. 
The second question is how the work will change when the computer is actually introduced and implemented. To analyse these two questions in greater detail, we may look at different effects of ICT on work. For example, the effect of the computer on productivity, how it may change the demand for workers in this job, but also whether the required educational level for the job will change, what will be the effect on the values of different skills, whether the product will be adapted, and how the working procedures within a company change.

\subsection{Who uses ICT?}

Let us first deal with the question under which circumstances the decision will be taken to acquire ICT to support the work. If we assume that the computer will only be introduced if it is profitable for the company, the decision will be based on whether (i) the efficiency of the work is increased by the computer, and whether (ii) the profits are large enough to justify the cost of the hardware and software concerned. Later in this paper, we will discuss the effects of continued ICT developments. To increase insight, it is useful to separate the two aspects of the cost-benefit analysis. Further development of ICT may (i) increase the effectiveness of hardware and corresponding software and other applications, but (ii) the usage costs may also decrease.

The efficiency of the production process will of course increase when an individual is able to carry out tasks faster as a result of the computer. The time gained may relate to the work that is computerized or to the work that cannot be taken over by the computer. If Task 1 is automated, the time required to carry out the task itself will be replaced by the time that is required to operate the computer adequately. The largest gain can therefore be achieved if Task 1 can easily be automated and the user is able to handle the computer efficiently. In principle, the activities that cannot be automated (Task 2), will continue to take as much time as before. It is also possible, however, that the introduction of the computer makes it possible to carry out Task 2 more efficiently. This reflects the possibility that technology and labour are complementary. By making optimal use of the possibilities of the computer in Task 1, Task 2 could also be carried out more efficiently. Accountancy might be a good example of an occupation in which Task 2 gains from such a complementarity. Accountants today need not do their calculations by means of mental arithmetic or use a notebook to check a company's books. They will use computers and spreadsheet applications to add up numbers, divide figures, et cetera. Accountants can now concentrate entirely on analysing and checking (by means of the computer) the correctness of the figures and detect any errors or fraud more quickly if the figures are incorrect. If the complementarity of the two tasks is high, Task 2 (the analysis) will also be completed in less time.

There are three points of view with respect to the employment effects of computer usage representing extreme examples of this conceptual framework. In the view that expects computers to take over the work of human beings, work consists merely of Task 1 that can be automated and there is little or no time required to operate the computers. As it is in particular the lower educated who perform such tasks, they are the first to fall victim. The second view states that work consists only of Task 1 that can be automated, but that computer skills are so important that keeping computers running requires a great deal of 
time and specific skills. As it is expected that in particular the higher educated have such skills, they will be the ones to carry out this computer work. Lastly, there is a view in which complementary skills determine the value of computer usage. Here the task to be automated is marginal and there is not much time to be gained. The advantage should then be obtained from increased efficiency of the complementary tasks.

It is interesting to see that even when computer skills are not important and there are no complementarity advantages to be gained, the introduction of ICT can nevertheless achieve time gains without the work disappearing completely. In this case, the employee need only carry out Task 2, while the computer takes over Task 1 completely.

A company will only decide to introduce ICT, however, if the costs involved match the time that can be gained. Time gained in the production process is translated into a productivity increase and constitute savings on labour costs. It is therefore attractive to acquire ICT if the costs of the set-up are lower than the wages that must be recovered. In addition to the amount of time saved, the wages of the employee(s) involved will determine whether the computer will ever pay itself back. This appears to be true even when the wages are not a proper reflection of productivity. If various institutional factors cause the wages in a particular occupational group to be relatively high compared to other occupational groups, ceteris paribus, computer will be introduced more rapidly. If an occupational group earns much less than could be expected on the basis of productivity, investments in ICT will be made less easily. The mechanism that determines if and when computers are introduced on the workplace, therefore depends on the wages earned by individuals rather than the computer skills or complementary skills of such workers.

This simple observation turns the Krueger comparison upside down. Even when we correct for personal characteristics and job characteristics, wage fluctuations explain the chances of individuals of having a computer. It is therefore not true that the higher educated will have computers sooner, but it is the higher paid who receive such devices first. The less relevant the equipment is for the job, the greater the wage difference must be to make its purchase profitable. That is the reason why relatively trivial tasks, such as emailing and word processing, have a great impact on wages. If a manager and his assistant spend an equal amount of time on the same task, and they are both equally good at it, then the profits of automation will compensate the costs of automation more easily in the case of the manager. After all, the manager earns much more than his assistant, which means that the time gained in his case generates a greater profit for the company.

As observed before, it is irrelevant here whether wages reflect productivity or not. Productivity differences may emerge, however, because an individual is capable of producing products of greater value or higher quality, but these may also arise because one person is able to carry out the work faster than another. Just like higher wages indicate greater speed of working, investments in ICT will be made less easily. After all, in the case of faster workers there is less time to be gained by computers taking over the work. 
Following this line of reasoning, we can state that when the costs of computer usage are reduced further, the introduction of the computer will become profitable for other jobs too. If the costs were reduced to zero, all jobs in which the introduction of ICT can result in time gain, would do so. If the possible applications and efficiency in ICT were to increase further, the group of jobs in which useful application is possible would also grow. If the costs are reduced sufficiently and the areas of application increase, eventually almost every job will probably use ICT.

This also means that the cost development of ICT usage is a crucial factor for the introduction of ICT at work. Especially because the technical infrastructure for ICT will have major positive effects, the economic policy to guide the price developments of this infrastructure properly, may have great implications for productivity increases on the labour market. The availability of software and digital information also determine the costs of computer usage. As these are complicated markets, in which the marginal costs of reproduction are practically zero, but the development costs can be considerable, market disturbances emerge easily (e.g. Borghans and Groot (1998)). If old legislation in the field of property law and competition are not adapted to these new issues, excessive costs could hinder the introduction of new ICT applications.

For a large part, the costs of the introduction of ICT will not depend on the number of employees in a company or a department who make use of the technology, but many of the costs will follow from the development and implementation for the company or department as a whole. As people must be able to work together within a department, it will often be difficult to allow some workers to use computer or communication systems and not others. As a result, it is to some extent not the individual wages themselves, but the average wages of the department in which one works that affect the decision whether or not to use ICT.

\subsection{Productivity, demand and wages}

The introduction of ICT will lead to productivity increases. These are equal to the relative time gain achieved in the production process as a result of the computerization of Task 1. If the total production volume remains the same, the demand for employees in this profession will decrease by a similar percentage. Production costs decrease less, because the decreasing wage costs are offset by the increasing costs for the use of ICT. In addition to this immediate reduction of the demand for labour as a result of productivity increases, the lower cost price per unit of product, however, will lead to an increase of the demand for the product concerned and hence indirectly to a higher demand for the labour involved. Eventually, the effect on employment depends on the size of the two effects. If demand is characterised by high price elasticity, efficiency improvements may lead to an increase of the demand for labour and this will create an upward pressure on wages. ${ }^{12}$ If we assume that ICT is introduced in particular among the higher educated, there will only be 'skill-biased technical

12. This is only a partial effect on wages. Because ICT will change the demand for a variety of professions, and wage changes in one submarket may affect other submarkets, it is difficult to get an overview of the final effects in a general balance. 
change' if this elasticity is sufficiently large, that is, an improvement of the position of the higher educated in relation to the position of the lower educated. In addition, if the costs of computer usage have decreased to such an extent after some time that ICT is introduced in all jobs in which time can be gained, these demand effects are equally likely to occur among lower-educated workers. Eventually, the effect of ICT on the demand for labour through this route, seems ambiguous and it is not likely that we will find the main explanation for 'skillbiased technical change' here.

\subsection{Which skills are important?}

We have shown that even if computer skills play no role and there is no complementarity, in which certain skills come into their own better because of the use of computers, the introduction of ICT can nevertheless be explained and it is plausible that workers with high wages are the first to make use of ICT. Even without an explicit role for computer skills and complementary skills, the value of different skills in the labour market will start to shift as a result of the introduction and diffusion of ICT. After all, the structure of the work is shifting, making the skills that promote productivity in the remaining work more important, whereas the importance of the skills that were required for the work that is now done by the computer will decrease. ${ }^{13}$

This does not mean that computer skills and complementarity cannot play a role in this process. In principle, this is an empirical issue and only thorough empirical research on the basis of a representative data set is able to show the shift in the importance of various skills. Here too, there may be 'skill-biased technical change.' This will be the case in particular if the value increases of those skills that are present in the higher educated. The examples given above, however, do not seem to support this. After all, work that is difficult to computerize includes both customer-friendliness and patience, and leadership skills.

\subsection{Required educational level}

The education and qualification requirements set by an employer for a particular job, can be regarded as a balance between the higher wages that must be paid for a higher educated employee and the additional productivity that such an employee may provide. In a job in which a higher educated employee adds little to productivity, compared to a lower educated employee, educational requirements will therefore not easily be raised (e.g. Borghans and De Grip (2000a) and (2000b)). It seems reasonable to assume that a higher educated worker will yield productivity benefits in particular in those activities that cannot easily be automated. $^{14}$

13. Felstead, Ashton and Green (2000) find some evidence for this for the United Kingdom in the nineties.

14. Autor, Levy and Murnane (2000) give a number of interesting counterexamples of work that is relatively easy to program $B$ and hence relatively easy to do for a computer $B$ while this would require special 'talents' in humans. The most obvious example of course is a chess player. 
Before ICT was introduced, increasing educational requirements meant that highly paid workers would also do work in Task 1 in which they were no better than workers with a lower educational background. This acted as a restraint on the qualification requirements that were set. After the introduction of ICT, activities such as Task 1 no longer play a role. Even if the higher educated is not more adept at carrying out the computerized Task 1 , it may be expected that employers will increase their educational requirements, because the importance of Task 2 increases. Groot and De Grip (1991) were among the first to show that the introduction of ICT leads to higher educational requirements. By comparing various branches of a large Dutch bank, which introduced front office and back office automation at different moments in time, they were able to show that automated branches did indeed increase their educational requirements. ${ }^{15}$

This shift in the importance of tasks constitutes a third possible cause of 'skill-biased technical change'. Whether it is a high-skilled job or a low-skilled job, after the introduction of ICT we may expect a gradual increase of the educational requirements in the job concerned. Within each job, it is not a change from an unskilled worker to an academic, but as an aggregate these demand shifts will change the employment structure as a whole. It can be expected that this effect is much more likely to lead to 'skill-biased technical change' than the previous possible effects. After all, shifts in the demand can be both to the advantage and to the disadvantage of the higher educated, while this increase of educational requirements within a particular job almost always moves in the same upward direction.

\subsection{Is work getting more complex or more standardized?}

Just as an employer may consider which educational level to demand for a particular job, he may also vary the nature of the product by putting greater emphasis on Task 1 that can be computerized, or instead on Task 2 that cannot be computerized. The choice of the product to manufacture will depend on the costs and benefits of the various combinations. If a product is standardized, it is likely that a greater part of the work will be routine work and capable of being automated. The costs will drop, but the value of the product will also decrease. On the other hand, more tailor-made work will be required for a greater amount of work that is difficult to automate. This will lead to higher costs, but will probably also make the product more valuable. The product that is actually manufactured, is therefore determined by the balance between these factors. The introduction of ICT applications will also upset this balance.

On the one hand, as we have indicated above, the routine part of the work (Task 1) becomes cheaper as a result of the introduction of ICT. This will give rise to a tendency to standardize the product. On the other hand, complementarity will also increase the productivity of non-automated work (Task 2). If this were the case, there would be a renewed trend to supply more tailor-made products. The eventual changes in the product will therefore

15. Doms, Dunne and Troske (1997) and Autor, Katz and Krueger (1998) find similar 'upgrading' effects for the United States. 
depend on the cost savings in the routine part on the one hand, and the achieved complementarity advantages on the other.

\section{Conclusions and policy implications}

The introduction and diffusion of computers and ICT has drastically changed the labour market and the economic landscape. Many tasks have been automated and many workers are able to work more efficiently. As a result, the labour market is also affected to a great extent by computer technology in PC's, but also in other ICT applications. Further diffusion of new ICT will only increase the importance of computers and computer-related technology.

In this paper, we have discussed the way in which people work with computer technology. On the basis of this analysis of the interaction between man and machine, we have shown which workers use ICT applications, what influence this has had on the content of their work, and what the implications are for the demand for various types of labour. Considered from the current view on the effects of computers and ICT on employment, our findings are startling. Just like there was an unjustified fear during the sixties and seventies of mass technological unemployment resulting from computers taking over the work of human beings, there is now no reason to be afraid that the population will miss the boat if we do not invest in computer skills in time. It is true that new computer techniques are initially used more by the higher educated than by the lower educated. But this is often - mistakenly used to arrive at the conclusion that special computer skills are needed to be able to use this new technology. The primary aspect is not the high educational level but the high salary that explains the introduction of ICT in these groups. In workers with high salaries, a small increase in productivity results in greater cost savings. As ICT becomes cheaper and more interesting applications emerge B we expect B almost everybody will come into contact with computer technology at the workplace. Because these new applications are meant to support people in their work, the use of this new technology will create few problems.

This does not mean, however, that nothing will change. The use of computer technology will increase productivity in many occupations. On the one hand, this will decrease the demand for the category of labour concerned, but on the other hand the lower production costs will also decrease the production price, which in turn will increase demand. As a result of such processes, the importance of certain activities will increase while that of others will decrease. As we expect that eventually both the higher and the lower educated will use ICT applications in their work, and these production increases may have both a positive and a negative effect on demand, an unambiguous 'skill-biased technical change' is not expected, as we indicated in Section 3.

As ICT applications take over work from human beings, the importance of various types of skills will undergo major changes in the near future. On the basis of the new production options, employers will reconsider the product range that their companies supply and the working methods used. Under certain circumstances, we expect that there will be more tailor-made work, while under other conditions there will be greater standardization of 
products. Some will benefit from the shift in the importance of skills on the labour market, while others will suffer disadvantages. Again, we do not expect that this process will be clearly to the advantage of the higher educated, because it is not only the value of skills relating to cognitive intelligence that will increase.

The third effect of greater penetration of ICT is that individuals at work are able to concentrate more on those activities that constitute the essence of their profession. Many secondary tasks will be taken over by the new technology. This means that employers will tend to increase the required qualifications within the various professions. After all, the costs of higher wages will be compensated by the fact that less time is lost on tasks in which these skills are not used. It is in particular this argument that gives rise to the expectation that the demand for higher educated workers will continue to grow. The computerization of the labour market therefore does lead to 'skill-biased technical change'. This form of 'skill-biased technical change', however, does not lead to a situation in which there is no work for the lower educated and an increasing scarcity of higher educated workers, resulting in a threatening digital split of society. The gradual nature of these shifts means that in the time to come, almost everybody will study longer and will need to spend a little more energy on increasing and maintaining knowledge levels, in order to be able to continue functioning properly on the labour market.

Our conclusions can therefore be summarized in three main points.

Firstly, it seems futile to us to invest greatly in computer skills. The increasing use of ICT will almost always be effected without any problems. What is more important is to carefully monitor the shifts that take place with respect to a variety of different skills. If the education system is able to anticipate these changes successfully, the integration of youths can be guaranteed in the future.

If there is any need for policies to streamline the integration of ICT at work, then it is much more useful to concentrate on policies and regulations relating to the infrastructure for ICT (the digital highway), the availability and development of software, et cetera. Because the price of ICT usage is an important determinant in the diffusion process, an underdeveloped or too expensive cable network, or a too protected software market, may constitute serious impediments to the growth potential. As current legislation on competitiveness is largely based on experience with old technology, lack of flexibility in this field may cause many problems.

It cannot yet be predicted how exactly the labour market will further change as a result of the introduction of computers and ICT. This depends to a large extent on ICT applications that are still to be developed, while the response to these developments may be very complex. Lastly, it is therefore of great importance to carefully monitor developments in the labour market, because only then will it become clear in time in which direction the labour market is moving. This demands different perspectives in research and hence also a new type of (experimental) data collection, with a much greater emphasis on the nature and content of the work, the required competences, and the available knowledge and skills of workers. Such an instrument would serve both research and policy-making. To be able to follow 
labour market developments adequately in the future, we will need to develop the tools used to measure skills, and researchers will need to have the possibility to test their insights in the developments on the labour markets against real-life situations. For policy-makers, such an instrument may constitute the basis for policies in the field of education, training, and labour, enabling them to also keep a finger on the pulse in a knowledge based economy.

\section{References}

Acemoglu, K.D. (1998), Why do new technologies complement skills? Directed technical change and wage inequality, Quarterly Journal of Economics, Vol. 113, no. 3, pp. 1055-1089.

Anderson, R.E. and A. Ronnkvist (1999), The presence of computers in American schools, (http://www.crito.uci.edu/TLC).

Ashton, D., B. Davies, A. Felstead and F. Green (1999), Work skills in Britain, ESRC Centre on Skills Knowledge and Organisational Performance (SKOPE), Oxford and Warwick Universities.

Autor, D.H., L.F. Katz and A.B. Krueger (1998), Computing inequality: Have computers changed the labor market? Quarterly Journal of Economics, Vol. 113, no. 3, pp. 1169-1213.

Autor, D.H., F. Levy and R.J. Murnane (2000), Computer cognition and human cognition: The skill content of recent technological change, mimeo, MIT.

Bell, B.D. (1996), Skill-biased technical change and wages: Evidence from a longitudinal data set, mimeo, Nuffield College.

Berman, E., J. Bound and Z. Griliches (1994), Changes in the demand for skilled labor within U.S. manufacturing industries, Quarterly Journal of Economics, Vol. 109, no. 2, pp. 367-398.

Berman, E., J. Bound and S.J. Machin (1998), Implications of skill-biased technological change: International evidence, Quarterly Journal of Economics, Vol. 113, no. 3, pp. 1245-1279.

Berman, E. and S.J. Machin (2000), Skill-biased technology transfers: Evidence of factor-biased technological change in developing countries, mimeo, Boston University.

Borghans, L., F. Green and K. Mayhew (eds.) (2001), Skills measurement and economic analyse, Oxford Economic Papers, Vol. 54, no. 3, forthcoming.

Borghans, L. and A. de Grip (eds.) (2000a), The overeducated worker? The economics of skill utilization, Cheltenham: Edward Elgar.

Borghans, L. and A. de Grip (2000b), Skills and low pay: Upgrading or overeducation? In: M. Gregory, W. Salverda and S. Bazen (eds.) Labour market inequalities; Problems and policies of low-wage employment in international perspective, Oxford: Oxford University Press, pp. 198-224.

Borghans, L. and L. Groot (1998), Superstardom and monopolistic power: Why media stars earn more than their marginal contribution to welfare, Journal of Institutional and Theoretical Economics, Vol. 154, no. 3, pp. 546-571. 
Borghans, L. and J. van Loo (1999), Skills measurement and wages, mimeo, ROA.

Borghans, L. and B. ter Weel (2000a), Do we need computer skills to use a computer? Evidence from the U.K., mimeo, ROA and MERIT.

Borghans, L. and B. ter Weel (2000b), Why pens changed the wage structure and computers did not: The returns to computer and pen use revisited, mimeo, ROA and MERIT.

Borghans, L. and B. ter Weel (2000c), What happens when agent T gets a computer? Mimeo, ROA and MERIT.

Bound, J. and G. Johnson (1992), Changes in the structure of wages in the 1980's: An evaluation of alternative explanations, American Economic Review, Vol. 82, no. 2, pp. 371-392.

Bresnahan, T.F. (1999), Computerisation and wage dispersion: An analytical reinterpretation, Economic Journal, Vol. 109, Features, pp. F390-F415.

Bresnahan, T.F., E. Brynjolfsson and L. Hitt (1998), How do information technology and work-place organization affect labor demand? Firm level evidence, mimeo, MIT.

Card, D., F. Kramarz and T. Lemieux (1999), Changes in the relative structure of wages and employment: A comparison of the United States, Canada, and France, Canadian Journal of Economics, Vol. 32, no. 4, pp. 843-877.

Caroli, E. and J. Van Reenen (1998), Human capital and organisational change: Evidence from British and French establishments in the 1980's and 1990's, mimeo, University College London.

Caselli, F. (1999), Technological revolutions, American Economic Review, Vol. 89, no. 1, pp. 78-102.

Chennells, L. and J. Van Reenen (1998), Establishment level earnings, technology and the growth of inequality: Evidence from Britain, Economics of Innovation and New Technology, Vol. 5, no. 1, pp. 139-164.

Department for Education and Employment (1999), Departmental Report; The Government's Expenditure Plans 1999-00 to 2001-02. London: The Stationery Office.

Desjonqueres, T., S.J. Machin and J. Van Reenen (1999), Another nail in the coffin? Or can the trade based explanation of changing skill structures be resurrected? Scandinavian Journal of Economics, Vol. 101, no. 3, pp. 533-554.

DiNardo J. and J.-S. Pischke (1996), The return to computer use revisited: Have pencils changed the wage structure too? NBER Working Paper 5606.

DiNardo J. and J.-S. Pischke (1997), The return to computer use revisited: Have pencils changed the wage structure too? Quarterly Journal of Economics, Vol. 112, no. 1, pp. 291-303.

Doms, M., T. Dunne and K. Troske (1997), Workers, wages and technology, Quarterly Journal of Economics, Vol. 112, no. 1, pp. 253-290. 
Dunne, T., L. Foster, J. Haltiwanger and K. Troske (2000), Wage and productivity dispersion in U.S. manufacturing: The role of computer investment, NBER Working Paper 7465.

Entorf, H. and F. Kramarz (1997), Does unmeasured ability explain the higher wages of new technology workers? European Economic Review, Vol. 41, no. 6, pp. 1489-1509.

Entorf, H., M. Gollac and F. Kramarz (1999), New technologies, wages and worker selection, Journal of Labor Economics, Vol. 17, no. 3, pp. 464-491.

Felstead, A., D. Ashton and F. Green (2000), Are Britain's workplace skills becoming more unequal? Cambridge Journal of Economics, Vol. 24, no. 6, pp. 709-727.

Freeman, C. and L. Soete (1994), Work for all or mass unemployment, London: Pinter.

Freeman, C. and L. Soete (1997), The economics of industrial innovation, Cambridge MA: MIT Press.

Goldin, C. and L.F. Katz (1998), The origins of technology-skill complementarity, Quarterly Journal of Economics, Vol. 113, no. 2, pp. 693-732.

Green, F. (1999), The value of skills, mimeo, University of Kent.

Green, F., A. Felstead and D. Gallie (1999), Computers are even more important than you thought: An analysis of the changing skill-intensity of jobs, mimeo, Centre for Economic Performance.

Griliches, Z. (1969), Capital-skill complementarity, Review of Economics and Statistics, Vol. 51, no. 2, pp. 465-468.

Groot, L. and A. de Grip (1991), Technological change and skill formation in the bank sector, Economics of Education Review, Vol. 10, no. 1, pp. 57-71.

Haisken-DeNew, J. P. and C.M. Schmidt (1999), Money for nothing and your chips for free? The anatomy of the pc wage differential, mimeo, Deutsches Institut für Wirtschaftsforschung, Diskussionspapiere.

Hamilton, B.H. (1997), Returns to computer skills and black-white wage differentials, mimeo, John M. Olin School of Business.

Handel, M.J. (1999), Computers and the wage structure, mimeo, The Jerome Levy Economics Institute.

Haskel, J. and Y. Heden (1999), Computers and the demand for skilled labour: Industry- and establishment-level panel evidence for the UK, Economic Journal, Vol. 109, Conference Proceedings, pp. C68-C79.

Katz, L. F. and K.M. Murphy (1992), Changes in relative wages, 1963-87: Supply and demand factors, Quarterly Journal of Economics, Vol. 107, no. 1, pp. 35-78.

Krueger, A. B. (1993), How computers have changed the wage structure: Evidence from microdata, 1984-1989, Quarterly Journal of Economics, Vol. 108, no. 1, pp. 33-60. 
Levy, F., A. Beamish, R. J. Murnane and D.H. Autor (1999), Computerization and skills: Examples from a car dealership, mimeo, MIT.

Levy, F. and R.J. Murnane (1996), With what skills are computers complements? American Economic Review, Vol. 86, Papers and Proceedings, pp. 258-262.

Lindbeck, A. and D.J. Snower (2000), Multi-task learning and the reorganization of work: From Tayloristic to Holistic organization, Journal of Labor Economics, Vol. 18, no. 3, pp. 353-376.

Lohberg, R. and T. Lutz (1968), Hoe werkt een computer? Deventer: Kluwer.

Machin, S.J. (1996), Changes in the relative demand for skills, in: A. Booth and D.J. Snower (eds.) Acquiring skills. New York: Cambridge University Press, pp. 129-146.

Machin, S.J. and J. Van Reenen (1998), Technology and changes in skill structure: Evidence from seven OECD countries, Quarterly Journal of Economics, Vol. 113, no. 3, pp. 1215-1244.

Miller, P.W. and C. Mulvey (1997), Computer skills and wages, Australian Economic Papers, Vol. 36, no. 1 , pp. 106-113.

Murnane, R.J., J.B. Willett and F. Levy (1995), The growing importance of cognitive skills in wage determination, Review of Economics and Statistics, Vol. 77, no. 2, pp. 251-266.

Murphy, K.M. and F. Welch (2000), Wage differentials in the 1990's: Is the glass half-full or half empty? Mimeo, University of Chicago.

OECD (1994), Employment outlook, Parijs: OECD.

Oosterbeek, H. (1997), Returns from computer use: A simple test on the productivity interpretation, Economics Letters, Vol. 55, no. 2, pp. 273-277.

Reader, W.J. (1980), Vijftig jaar Unilever, Londen: Heinemann.

Reilly, K. (1995), Human capital and information: The employer size-wage effect, Journal of Human Resources, Vol. 30, no. 1, pp. 1-18.

Ricardo, D. (1821), Principles of political economy and taxation, London.

Second Report of the National Skills Task Force (1999), Delivering Skills for All. London: The Department for Education and Employment.

Soete, L. (1987), Employment, unemployment and technical change: A review of the economic debate, in: C. Freeman and L. Soete (eds.), Technical change and full employment, Oxford and New York: Blackwell, pp. 2-35.

Spenner, K.I. (1985), The upgrading and downgrading of occupations, Review of Educational Research, Vol. 55, no. 1, pp. 125-154.

Weinberg, B.A. (2000), Computer use and the demand for female workers, Industrial and Labor Review, Vol. 53, no. 1, pp. 290-308. 


\section{Appendix}

\section{A. Data}

The data we utilize in this paper have been collected in a survey conducted in the first half of 1997 called the Skills Survey of the Employed British Workforce. The survey includes a relatively small, but representative, number of individuals $(n=2,467)$ from the UK Participants were asked several dozens of questions on their labour market situation to obtain precise information on various aspects of their jobs including qualifications, responsibilities, skills, the tasks they carry out at work and training. See Ashton, Davies, Felstead and Green (1999) for a description of the survey and the full questionnaire. They also elaborate on the (theoretical and econometric) concepts deployed and the methods used to conduct the survey and to derive indices of various types of job skills in the survey.

50.8 percent of the respondents are male; the age of the respondents lies between 20 and 60 of which 22.6 percent is between 20-29, 31.4 percent between 30-39, 26.9 percent between 40-49 and 19.1 percent between 50 and 60; 89.3 percent of the respondents is employee, the remaining part is self-employed; 76.9 percent of the respondents works fulltime, the remaining ones part-time; the allocation of respondents among sectors is the following (percentages in parentheses): Agriculture, Hunting and Fishing (1.5 percent), Forestry ( 0.1 percent), Fishing ( 0.1 percent), Mining and Quarrying (0.3 percent), Manufacturing (19.9 percent), Electricity, Gas and Water Supply (0.7 percent), Construction (6.3 percent), Wholesale and Retail Trade (14.4 percent), Hotels and Restaurants (3.7 percent), Transport (7.3 percent), Financial Intermediation (4.3 percent), Real Estate (8.8 percent), Public Administration (6.9 percent), Education (8.0 percent), Health and Social Work (12.4 percent), Other Community (4.4 percent), Private Households with Employment Persons ( 0.4 percent); the following occupations are identified (percentages in parentheses): managers and administrators (14.0 percent), Professionals (10.3 percent), Associate Professionals (10.1 percent), Clerical and Secretarial (17.6 percent), Craft and Related (12.1 percent), Personal and Protective Services (11.0 percent), Sales (7.5 percent), Plant and Machine Operatives (10.5 percent) and Other (6.9 percent).

\section{B. Definition of skills in Table 6}

In Table 6 we have added for each level of computer usage the importance of particular skills. The question asked to individuals surveyed is the following: "When your job involves ...., are you able to do this effectively?" Six possible answers were offered: always, nearly always, often, sometimes, hardly ever and a remaining category does not apply. The particular skills, besides computer skills, asked for are (1) analysing complex problems in depth, (2) writing long documents with correct spelling and grammar, (3) working hard even when not being supervised, (4) dealing with people, (5) organising your own time, (6) carrying out calculations using decimals, percentages or fractions, (7) joining in a team effort, (8) making sure that things are correct, (9) noticing when there is a mistake, (10) working out the cause of problems or faults, (11) persuading or influencing others, (12) helping other team members, (13) having knowledge or understanding of how the or- 
ganisation works, (14) knowing how to use/operate the tools/equipment/machinery required in the job, (15) having enough physical stamina to carry out physical activities for long periods, (16) acting without being prompted, (17) being skilled enough with your hands to mend, repair, assemble, construct or adjust things, (18) having specialist knowledge or understanding, (19) being physically strong enough to carry, push, or pull heavy objects, (20) checking things to ensure that there are no errors, (21) reading and understanding written information such as forms, notices, or signs, (22) reading and understanding long documents such as long reports, manuals, articles, or books, (23) handling problems with little guidance, (24) writing notes or filling in forms with correct spelling and grammar, (25) adding, subtracting, multiplying, or dividing numbers correctly, (26) being relied upon to get the work done, (27) carrying out calculations using advanced mathematical or statistical procedures, (28) completing tasks on time, (29) using your initiative, (30) spotting problems or faults, (31) thinking ahead, (32) making effective speeches or presentations, (33) counselling, advising, or caring effectively for others, (34) planning your own activities, (35) planning the activities of others, (36) selling a product or service, (37) working very hard, (38) knowing about the particular products or services related to your job, (39) keeping going even when things get tough, (40) thinking of solutions to problems, (41) writing short documents with correct grammar and spelling, (42) playing close attention to detail, (43) instructing, training, or teaching people, (44) reading and understanding short documents such as short reports, letters, or memos, and (45) listening carefully to colleagues. 